@ERSpublications

ENaC polymorphism p.W493R is associated with bronchiectasis but does not necessarily lead to aberrant ion conductance http://ow.ly/S5Mwj

Jessica Rademacher ${ }^{1}$, Angela Schulz ${ }^{2,3}$, Silke Hedtfeld ${ }^{2}$, Frauke Stanke ${ }^{2,3}$, Felix Ringshausen ${ }^{1,3}$, Tobias Welte ${ }^{1,3}$ and Burkhard Tümmler,3

${ }^{1}$ Dept of Respiratory Medicine, Hannover Medical School, Hannover, Germany. ${ }^{2}$ Clinic for Paediatric Pneumology, Allergology and Neonatology, Hannover Medical School, Hannover, Germany. ${ }^{3}$ Biomedical Research in Endstage and Obstructive Lung Disease (BREATH), German Center for Lung Research, Hannover, Germany.

Correspondence: Burkhard Tümmler, Clinical Research Group, Clinic for Paediatric Pneumology, Allergology and Neonatology, OE 6710, Hannover Medical School, Carl-Neuberg-Str. 1, D-30625 Hannover, Germany.

E-mail: tuemmler.burkhard@mh-hannover.de

Received: July 132015 | Accepted after revision: Aug 122015 | First published online: Oct 92015

Support statement: This work was supported by a grant of the Deutsche Forschungsgemeinschaft (grant number: SFB 621, C7). Funding information for this article has been deposited with FundRef.

Conflict of interest: Disclosures can be found alongside the online version of this article at erj.ersjournals.com

Acknowledgements: We thank Rabea Gatzke (Dept of Respiratory Medicine, Hannover Medical School, Hannover, Germany) for organisational support.

\title{
References
}

1 McShane PJ, Naureckas ET, Tino G, et al. Non-cystic fibrosis bronchiectasis. Am J Respir Crit Care Med 2013; 188: 647-656.

2 Mall M, Grubb BR, Harkema JR, et al. Increased airway epithelial $\mathrm{Na}^{+}$absorption produces cystic fibrosis-like lung disease in mice. Nat Med 2004; 10: 487-493.

3 Azad AK, Rauh R, Vermeulen F, et al. Mutations in the amiloride-sensitive epithelial sodium channel in patients with cystic fibrosis-like disease. Hum Mutat 2009; 30: 1093-1103.

4 SheridanMB, Fong P, Groman JD, et al. Mutations in the beta-subunit of the epithelial $\mathrm{Na}^{+}$channel in patients with a cystic fibrosis-like syndrome. Hum Mol Genet 2005; 14: 3493-3498.

5 Rowe SM, Clancy JP, Wilschanski M. Nasal potential difference measurements to assess CFTR ion channel activity. Methods Mol Biol 2011; 741: 69-86.

6 Bombieri C, Claustres M, De Boeck K, et al. Recommendations for the classification of diseases as CFTR-related disorders. J Cyst Fibros 2011; 10: Suppl 2, S86-S102.

7 Sermet-Gaudelus I, Girodon E, Sands D, et al. Clinical phenotype and genotype of children with borderline sweat test and abnormal nasal epithelial chloride transport. Am J Respir Crit Care Med 2010; 182: 929-936.

8 Baker E, Jeunemaitre X, Portal AJ, et al. Abnormalities of nasal potential difference measurement in Liddle's syndrome. J Clin Invest 1998; 102: 10-14.

9 Yang K-Q, Xiao Y, Tian T, et al. Molecular genetics of Liddle's syndrome. Clin Chim Acta 2014; 436: 202-206.

\section{Lung positron emission tomography with FDG in patients with haematological malignancies and acute respiratory failure}

To the Editor:

Diagnostic strategy in haematology patients with pulmonary infiltrates relies on different approaches $[1,2]$. Over the past decade, the use of ${ }^{18} \mathrm{~F}$-fluorodeoxyglucose (FDG) positron emission tomography (PET) has been widely used to detect inflammatory and malignant processes, to evaluate the extent of a malignancy, and to ascertain response to therapy. Hот et al. [3] reported diagnostic contribution of FDG-PET in patient with invasive fungal infection. More recently, VERONESI et al. [4] reported PET findings in the diagnostic work-up of screening-detected lung nodules. PET-computed tomography (CT) was highly sensitive for the differential diagnosis of indeterminate nodules detected at baseline, nodules $\geqslant 15 \mathrm{~mm}$ and solid nodules [4]. However, FDG-PET has never been evaluated in unselected patients with acute respiratory failure that complicates haematological malignancies. 
TABLE 1 Clinical features, pulmonary diagnosis, ${ }^{18} \mathrm{~F}$-fluorodeoxyglucose (FDG) positron emission tomography (PET) results and definite pulmonary diagnoses in patients with haematological malignancies and acute respiratory failure

\begin{tabular}{|c|c|c|c|c|c|c|c|}
\hline Case & $\begin{array}{l}\text { Gender, } \\
\text { age years }\end{array}$ & Malignancy & Definite diagnosis & CT findings & BAL findings & $\begin{array}{l}\text { FDG-PET } \\
\text { findings }\end{array}$ & Diagnostic test \\
\hline 1 & Male, 41 & $\begin{array}{l}\text { Haemophagocytic } \\
\text { lymphohistiocytosis }\end{array}$ & Kaposi Sarcoma & Diffuse ground glass opacities & Alveolar haemorrhage & $\begin{array}{l}\text { Diffuse and } \\
\text { intense }\end{array}$ & Lung biopsy \\
\hline 2 & Female, 73 & Myelodysplasia & Kaposi Sarcoma & $\begin{array}{l}\text { Peribronchovascular nodules, } \\
\text { diffuse ground glass opacities }\end{array}$ & $\begin{array}{c}\text { Increased number of } \\
\text { BAL cells, } 90 \% \text { macrophages }\end{array}$ & $\begin{array}{l}\text { Diffuse and } \\
\text { intense }\end{array}$ & Bronchial biopsy \\
\hline 3 & Female, 32 & Hodgkin lymphoma & Tuberculosis & Segmental pneumonia & $\begin{array}{c}\text { Increased number of BAL cells, } \\
40 \% \text { neutrophils, } 30 \% \\
\text { lymphocytes }\end{array}$ & $\begin{array}{l}\text { Focal and } \\
\text { intense }\end{array}$ & Sputum \\
\hline 4 & Male, 62 & $\begin{array}{c}\text { Chronic myelomonocytic } \\
\text { leukaemia }\end{array}$ & $\begin{array}{l}\text { Pulmonary infiltration } \\
\text { from the malignancy }\end{array}$ & Centrolobular nodules & $\begin{array}{l}\text { Alveolitis with } 90 \% \text { neutrophils } \\
\text { and myelomonocytic cells }\end{array}$ & $\begin{array}{l}\text { Diffuse and } \\
\text { moderate }\end{array}$ & BAL \\
\hline 5 & Male, 63 & MALT lymphoma & $\begin{array}{l}\text { Pulmonary infiltration } \\
\text { from the malignancy }\end{array}$ & Diffuse ground glass opacities & Normal & $\begin{array}{l}\text { Diffuse and } \\
\text { moderate }\end{array}$ & Lung biopsy \\
\hline 6 & Female, 54 & $\begin{array}{l}\text { Intravascular large } \\
\text { B cell lymphoma }\end{array}$ & $\begin{array}{l}\text { Pulmonary infiltration } \\
\text { from the malignancy }\end{array}$ & $\begin{array}{l}\text { Peribronchovascular nodules, } \\
\text { localised ground glass opacities }\end{array}$ & Normal & $\begin{array}{l}\text { Diffuse and } \\
\text { moderate }\end{array}$ & Bronchial biopsy \\
\hline 7 & Female, 28 & Hodgkin lymphoma & $\begin{array}{l}\text { Pulmonary infiltration } \\
\text { from the malignancy }\end{array}$ & $\begin{array}{l}\text { Diffuse ill-defined alveolar } \\
\text { consolidation }\end{array}$ & Not performed & $\begin{array}{l}\text { Diffuse and } \\
\text { moderate }\end{array}$ & Marrow smear \\
\hline 8 & Female, 59 & MALT lymphoma & $\begin{array}{l}\text { Pulmonary infiltration } \\
\text { from the malignancy }\end{array}$ & Diffuse ground glass opacities & Normal & $\begin{array}{l}\text { Diffuse and } \\
\text { moderate }\end{array}$ & Lung biopsy \\
\hline 9 & Female, 54 & $\begin{array}{l}\text { Diffuse large B cell } \\
\text { lymphoma }\end{array}$ & $\begin{array}{l}\text { Pulmonary infiltration } \\
\text { from the malignancy }\end{array}$ & Peribronchovascular nodules & $\begin{array}{l}\text { Alveolitis, tumoral B-cell } \\
\text { infiltration }\end{array}$ & $\begin{array}{l}\text { Diffuse and } \\
\text { moderate }\end{array}$ & BAL \\
\hline 10 & Male, 70 & $\begin{array}{l}\text { Pleiomorph NHT } \\
\text { lymphoma }\end{array}$ & Pneumocystis & Diffuse ground glass opacities & Not performed & $\begin{array}{l}\text { Diffuse and } \\
\text { moderate }\end{array}$ & Sputum \\
\hline 11 & Male, 62 & $\begin{array}{l}\text { Chronic lymphoid } \\
\text { leukaemia }\end{array}$ & Pneumocystis & Diffuse ground glass opacities & $\begin{array}{l}\text { Increased number of } \\
\text { BAL cells, } 80 \% \text { lymphocytes }\end{array}$ & $\begin{array}{l}\text { Diffuse and } \\
\text { moderate }\end{array}$ & BAL \\
\hline 12 & Male, 47 & Burkitt lymphoma & Invasive aspergillosis & $\begin{array}{l}\text { Diffuse ill-defined } \\
\text { alveolar consolidation }\end{array}$ & Not performed & $\begin{array}{l}\text { Diffuse and } \\
\text { moderate }\end{array}$ & $\begin{array}{l}\text { Circulating } \\
\text { galactomannan } \\
\text { and sputum }\end{array}$ \\
\hline 13 & Male, 12 & Acute myeloid leukaemia & $\begin{array}{l}\text { Zygomycete } \\
\text { pneumopathy }\end{array}$ & $\begin{array}{l}\text { Ill-defined consolidation, } \\
\text { halo sign }\end{array}$ & Necrotic cells & $\begin{array}{l}\text { Focal and } \\
\text { moderate }\end{array}$ & Biopsy \\
\hline 14 & Female, 49 & Follicular lymphoma & $\begin{array}{l}\text { Geotrichum } \\
\text { pneumopathy }\end{array}$ & $\begin{array}{l}\text { Not performed } \\
\text { (severe ARDS) }\end{array}$ & Normal cells & $\begin{array}{l}\text { Focal and } \\
\text { moderate }\end{array}$ & BAL \\
\hline 15 & Male, 46 & Mantle lymphoma & Invasive aspergillosis & Not performed & Not performed & $\begin{array}{l}\text { Diffuse and } \\
\text { moderate }\end{array}$ & $\begin{array}{l}\text { Circulating } \\
\text { galactomannan }\end{array}$ \\
\hline 16 & Male, 68 & $\begin{array}{c}\text { Diffuse large B cell } \\
\text { lymphoma }\end{array}$ & Viral infection & $\begin{array}{l}\text { Diffuse ground } \\
\text { glass opacities }\end{array}$ & Not performed & $\begin{array}{l}\text { Diffuse and } \\
\text { moderate }\end{array}$ & $\begin{array}{l}\text { Nasopharyngeal } \\
\text { aspirate }\end{array}$ \\
\hline 17 & Male, 71 & $\begin{array}{l}\text { Myelodysplastic } \\
\text { syndrome }\end{array}$ & Bacterial pneumonitis & Not performed & Not performed & $\begin{array}{l}\text { Focal and } \\
\text { mild }\end{array}$ & CT scan \\
\hline 18 & Female, 73 & $\begin{array}{c}\text { Chronic myelomonocytic } \\
\text { leukaemia }\end{array}$ & Bacterial pneumonitis & Not performed & Not performed & $\begin{array}{l}\text { Focal and } \\
\text { mild }\end{array}$ & CT scan \\
\hline 19 & Male, 63 & $\begin{array}{l}\text { Chronic myeloid } \\
\text { leukaemia }\end{array}$ & $\begin{array}{c}\text { Cardiogenic pulmonary } \\
\text { oedema }\end{array}$ & Not performed & Not performed & Normal & Echocardiography \\
\hline 20 & Male, 80 & $\begin{array}{l}\text { Chronic lymphoid } \\
\text { leukaemia }\end{array}$ & $\begin{array}{l}\text { Patent foramen ovale } \\
\text { with anatomic shunt }\end{array}$ & Normal & Not performed & Normal & $\begin{array}{c}\text { Contrast } \\
\text { echocardiography }\end{array}$ \\
\hline
\end{tabular}

CT: computed tomography; BAL: bronchoalveolar lavage; MALT: mucosa-associated lymphoid tissue; NHT: non-Hodgkin lymphoma; ARDS: acute respiratory distress syndrome. Parenchymal PET metabolic activity (maximum standardised uptake value): normal 0-2, focal and mild 2-4, moderate 4-8, intense $>8$. 
We report the results from a prospective pilot study during which critically ill haematology patients with pulmonary infiltrates benefited from a FDG-PET in addition to routine diagnostic and therapeutic management. Diagnoses were made mostly by noninvasive tests and bronchoalveolar lavage (BAL) fluid analysis; in addition, six patients had bronchial or pulmonary biopsies. FDG-PET was performed between day 1 and day 5, and completed by two senior radiologists specialised in nuclear medicine. None of the patients was intubated at the time of PET-CT, and all received high flow oxygen or intermittent noninvasive mechanical ventilation. According to the level of maximum standardised uptake value (SUVmax), patients were classified as having normal (0-2), mild (2-4), moderate (4-8) or intense (>8) pulmonary parenchymal metabolic activity. Table 1 summarises individual demographic, clinical and FDG-PET data. No adverse effects were observed after isotope injection. Pulmonary lesion related to lymphoma and fungal or viral infection presented with moderate parenchymal activity, whereas bacterial pneumonia presented with focal and mild lung parenchymal activity. Intense lung parenchymal activity was observed with pulmonary tuberculosis (one patient) and pulmonary Kaposi sarcoma (two patients). Normal FDG-PET was associated with normal lungs but cardiac abnormalities (two patients).

The ability of lung PET-CT with a SUVmax $>4$ to detect pulmonary infiltration by the malignancy had a sensitivity of $100 \%$ and a specificity of $33.33 \%$. Also, with a prevalence of malignant infiltration of $40 \%$, the negative predictive value was $100 \%$ and the positive predictive value was $50 \%$. Furthermore, the performances of lung PET-CT with a SUVmax $>4$ were identical than above to detect pulmonary infiltration by opportunistic infection (which prevalence was also $40 \%$ ).

This preliminary evaluation of FDG-PET in haematology patients with acute respiratory failure depicts FDG-PET patterns that have not been previously reported. We are not able to provide a specific picture related to a single aetiology. However, since there is a direct relationship between diagnosis and prognosis in these patients [1], we believe that every emerging diagnostic strategy needs to be appraised and evaluated carefully to assess its possible contribution to diagnosis and treatments. Further description of FDG-PET patterns in unselected haematology patients with pulmonary involvement is warranted. This prospective evaluation may contribute to the identification of aetiology of pulmonary involvement, to report on the extent of the inflammatory or infectious process, and also to estimate diagnosis contribution of FDG-PET in patients not identified using conventional diagnostic methods. To do so, future studies will need to assess correlations with conventional CT and morphological and immunological features in cells recovered from BAL fluids. In this study of 20 patients, SUVmax was not correlated with the number and the type of BAL cells. Hence, diagnostic performance of lung PET-CT will need to be adjusted for accompanying inflammatory reaction in the normally aerated lung with respect to their neutrophil activation and on correlation of FDG-PET with conventional CT. Only such an evaluation would help determine whether PET-CT can replace conventional CT and bronchoscopy and BAL fluid cytological analysis. Last, patient follow-up using PET-CT may help correlate lung metabolic activity and respiratory situation, in order to assess whether patients are responsive to anti-inflammatory, anti-tumoural or anti-infectious agents.

In summary, these preliminary descriptive results provide interesting insights on the use of PET-CT in immunocompromised patients with pulmonary infiltrates. However, they raise more questions than they bring answers. Studies are needed to confirm these results on a larger scale. Also, investigations to assess diagnostic performance of PET-CT as compared to a well-accepted gold standard, such as pulmonary biopsy, are warranted.

0 @ERSpublications

Lung FDG-PET may help to identify aetiology of pulmonary infiltrates in immunocompromised patients http://ow.ly/S24gC

Marc Pineton De Chambrun, Virginie Lemiale and Élie Azoulay

Medical Intensive Care and Nuclear Medicine Department, Paris 7 University, INSERM U517 APHP, Paris, France.

Correspondence: Élie Azoulay, Saint-Louis hospital, Medical Intensive Care Unit, ECSTRA Team, Biostatistics and Clinical Epidemiology, UMR 1153 (Center of Epidemiology and Biostatistic Sorbonne Paris Cité, CRESS), INSERM, Paris Diderot Sorbonne University, 1 Avenue Claude Vellefaux, 75010 Paris, France. E-mail: elie.azoulay@sls.aphp.fr

Received: Nov 102014 | Accepted after revision: July 222015 | First published online: Sept 242015

Conflict of interest: None declared.

\section{References}

1 Azoulay E, Mokart D, Lambert J, et al. Diagnostic strategy for hematology and oncology patients with acute respiratory failure: randomized controlled trial. Am J Respir Crit Care Med 2010; 182: 1038-1046.

2 Azoulay E, Schlemmer B. Diagnostic strategy in cancer patients with acute respiratory failure. Intensive Care Med 2006; 32: 808-822. 
3 Hot A, Maunoury C, Poiree S, et al. Diagnostic contribution of positron emission tomography with [18F] fluorodeoxyglucose for invasive fungal infections. Clin Microbiol Infect 2011; 17: 409-417.

4 Veronesi G, Travaini LL, Maisonneuve P, et al. Positron emission tomography in the diagnostic work-up of screening-detected lung nodules. Eur Respir J 2015; 45: 501-510.

\title{
Amoxicillin for clinically unsuspected pneumonia in primary care: subgroup analysis
}

\author{
To the Editor:
}

Antibiotic treatment is recommended for pneumonia [1, 2]. However, some studies have suggested that the milder spectrum of pneumonia in primary care does not have important adverse consequences if missed and, therefore, managed without antibiotics [3-5]. Better insight in the effects of antibiotics for pneumonia in primary care could improve patient information and management.

The aim of our study was to assess whether antibiotic treatment influenced outcome in patients presenting with acute lower respiratory tract infection (LRTI) with a radiologically proven, but clinically unsuspected, pneumonia compared to those without pneumonia.

This was a secondary analysis of a randomized, placebo controlled trial of amoxicillin for acute LRTI in 16 primary research networks in 12 European countries from October 2007 until April 2010. More details on this GRACE-10 study (Genomics to combat Resistance against Antibiotics in Community-acquired LRTI in Europe, www.gracelrti.org) have been reported elsewhere [6]. Eligible patients were aged $\geqslant 18$ years who consulted their general practitioner (GP) for the first time with an acute cough (duration of $\leqslant 28$ days) as the main symptom. Exclusion criteria were clinically suspected pneumonia [7], based on focal chest signs (focal crepitations and bronchial breathing) and systemic features (high fever, vomiting and severe diarrhoea); pregnancy, allergy to penicillin, treatment with antibiotics in the previous month and immunodeficiency. The study was approved by ethics committees in all participating countries and all participants provided written informed consent.

Patients who agreed to randomisation were allocated to receive amoxicillin $(1 \mathrm{~g}$ three times daily for 7 days) or placebo, by the GP dispensing sequentially numbered randomised containers.

GPs recorded patients' clinical signs, and comorbidities on a case report form. They also registered 14 baseline symptoms (cough, phlegm, shortness of breath, wheeze, runny nose, fever, chest pain, muscle aching, headache, disturbed sleep, feeling generally unwell, interference with normal activities/work, confusion/ disorientation and diarrhoea) on a 4-point Likert-scale from "no problem" to "severe problem". Baseline symptom severity was calculated by summing the scores of the symptoms and rescaling them to make them range between 0 and 100. Patients filled in a daily symptom diary during their illness for up to 28 days for the same symptoms on a 7 -point Likert scale $(0=$ no problem, $1=$ very little problem, $2=$ slight problem, $3=$ moderately bad, $4=$ bad, $5=$ very bad and $6=$ as bad as it could be). This diary was previously validated and shown sensitive to change [8]. If the diary was not returned after 4 weeks, brief information about symptom duration and severity were collected with either a short questionnaire or a standardised telephone call.

Chest radiographs were taken for each patient within 7 days of first presentation, but preferably within 3 days. Pneumonia was determined by radiologists, who were blind to all other information when they judged chest radiographs. In analysis reported here we defined pneumonia as all patients in whom the radiologist diagnosed pneumonia based on the chest radiograph [9].

Outcomes were duration of symptoms rated by patients as "moderately bad or worse" after initial presentation, symptom severity on days 2-4 after the index consultation, and worsening of illness, defined as a revisit to the GP with worsening symptoms, new symptoms, new signs, or illness necessitating admission to hospital within 4 weeks after the first consultation [6].

The effectiveness of the antibiotics was compared in patients with radiologically proven pneumonia compared to those without pneumonia for all three outcomes. Data were analysed using linear regression models. Cox regression was used for the duration of symptoms allowing for censoring, simple linear regression for 